\title{
DEVELOPMENT OF INSTITUTE OF ENERGY SAVING AND ENERGY MANAGEMENT RESEARCHES IN THE FIELD OF GEOENGINEERING
}

(C) V. Kravets

The article justifies a new understanding of the term "geoengineering" from the standpoint of the specialty "Mining". According to it, the formation of the Herald sections is proposed. They reflect the professional interests of scientific and teaching staff not only in the Department of Geoengineering, but also in other departments of the IEE, which carry out scientific research and applied research in related fields. The article gives a brief excursion into the history of formation of the staff of the department, its main scientific achievements, directions of cooperation with domestic and foreign scientific and scientific-pedagogical institutions, prospects of further growth.

Keywords: geoengineering, geospheres, geographical engineering, climate engineering, mining, scientific directions, underground urbanism, structural elements of construction

\section{VYNOSLAVSKIY VASILIY MYKOLAYOVICH}

\section{(C) S. Denysiuk, Y. Shulga}

The article was awarded to the honored practitioner of the URSR graduate School, the laureate of the State Prize of Ukraine, professor Vynoslavskiy Vasiliy Mikolayovich, a stretch of 27 years dean of the faculty of mining of the Kiev Polytechnic Institute. 14 September 2020 year 100 years from the day of the birth of him. The article briefly describes his life path and achievements, his life position and scientific achievements.

Keywords: anniversary, 100 years, Vynoslavskiy Vasiliy Mykolayovich, Honored Worker, Mining Faculty, KPI.

GEOMECHANIC AND GEOTECHNICAL

\section{MODELING AND PRACTICAL APPLIKCATION OF A POWER FIELD AT CONIC CHARGE EXPLOSION}

\author{
(C) V. Kravets, A. Shukurov
}

\section{МОДЕЛЮВАННЯ І ПРАКТИЧНЕ ВИКОРИСТАННЯ СИЛОВОГО ПОЛЯ ПІД ЧАС ВИБУХУ КОНІЧНОГО ЗАРЯДУ}

(C) В.Г.Кравець, А.М. Шукюров

Наведено аналіз характеру формування полів ізоденс продуктів вибуху конічного заряду, отриманих шляхом математичного моделювання. Визначено особливості поширення енергетичного поля в залежності від напрямку ініціюючого усіченого конічного заряду. Обговорюється комплексний характер використання проміжного бойовика в свердловину заряді у вигляді усіченого конуса при його розташуванні в донній частині свердловини. Встановлено, що форма поля ізоліній щільності ПД обумовлена в першу чергу формою заряду незалежно від місця його ініціювання; переважний розвиток поля відбувається відносно осі $\mathrm{Z}$, тобто вздовж осі $\mathrm{X}$ конічного заряду з боку дії вузької його частини. Це обумовлено розлітанням продуктів детонації по нормалі до похилої поверхні конуса. Якщо загальну площу поля щільностей ПД 
пов'язувати з загальною енергією вибуху, надається можливість перерозподілу потоку енергії за рахунок насамперед орієнтації основ та бічних сторін усіченого конусного заряду, а затим - місця його ініціювання. Управління динамікою і напрямком розвитку силового поля можливе шляхом вибору місця прикладання ініціюючого імпульсу, а саме, розташуванням ініціатора з протилежної основи заряду для розвитку процесу в потрібному напрямку зосередження енергії вибуху. Завдяки специфічній «грушоподібній» формі випромінюваного енергетичного поля вибух оберненого конічного бойовика на стадії ініціювання основного (свердловинного) заряду спрямовує вектор початкової ділянки фронту хвилі напружень в бік верхньої вільної поверхні, тобто в бік поверхневих шарів, розташованих на рівні набивки. Ця область не піддається безпосередній дії системи стискуючих радіальних та розтягуючих тангенціальних навантажень від вибуху заряду в свердловині. зміна напрямку розвитку силового поля в бік верхніх шарів породи має сприяти більш якісному подрібненню цієї частини масиву. Такий спосіб можна реалізувати, використовуючи механізм взаємодії породних мас, що переміщуються назустріч і додатково руйнуються аналогічно умовам короткосповільненого підривання за врубовою схемою, тобто на механізм взаємодії на рівні більш повільного процесу - співударяння (стикання) мас, спрямованого в сторону верхньої вільної поверхні. Одночасне нижне ініціювання подовжених зарядів в сусідніх рядах породжує нахилені до вільної поверхні уступу зустрічні фронти (рис. ). Фактично в цьому випадку реалізується схема клинового або трапеційного врубу, але орієнтованого замість бічної вільної поверхні в бік покрівлі уступу, яка через іiї значну площу є основним джерелом негабаритних фракцій. полягає в одночасному паралельному підриванні трьох суміжних рядів свердловинних зарядів, що трактуються в якості одної групи, з наступним короткосповільненим підриванням суміжної трьохрядної групи тощо. Реалізація такої схеми дозволяє використати іiі переваги завдяки поєднанню механізмів переміщення мас у вертикальному напрямку та традиційного переміщення із співударянням ділянок масиву у горизонтальному напрямку. Переваги застосування мішаної схеми комутації мережі доведено промисловими випробуваннями методу.

Ключові слова: зосереджений заряд, математичне моделювання, ізолінії щуільності, потік енергії, режим ініціювання, вектор поля, перебур.

\section{FREQUENCY DISPERSION DEPENDENCE OF DIELECTRIC PERMITTIVITY OF CRYOGENIC ROCKS AT THE MACRO LEVEL}

\section{(C) A. Kryuchkov, A. Bakhtyn}

Purpose. The purpose of this article is to establish the analytical expression of the frequency dispersion dependence of the real part of the dielectric permittivity of cryogenic rocks according to experimental studies. Methodology. Analytical and experimental investigations of the dependence of dielectric permittivity of cryogenic rocks on the field frequency of applied loads at the macro level have been carried out. An empirical analysis of the obtained results was carried out and a comparison of these data with experimental data was performed to prove the adequacy of the proposed mathematical models. Findings. The dielectric permittivity decreases exponentially with increasing frequency at all temperature values. The dependence parameter that corresponds to the frequency at the moment of electrical relaxation (anomalous dispersion zone) shifts toward low frequencies as the temperature decreases. The maximum and minimum values of the dielectric permittivity of cryogenic rocks are constant and independent of temperature change for a particular cryogenic rock and are dependent on humidity, mineralization and morphological structure. Originality. In this article, mathematical expressions are developed to describe the frequency 
dependence of dielectric permittivity under low frequency and high frequency loading, which is described by a single analytical dependence. Practical implications. The practical significance of the results obtained is the ability to establish seismic-acoustic, elasticdeformation and strength properties of rocks through the study of the characteristics of the electromagnetic properties of cryogenic rocks. Conclusions. The obtained analytical dependence of the dielectric permittivity of mountain cryogenic rocks in the form of a double exponent allows to adequately describe the influence of an external electric field, taking into account the humidity and temperature of the rocks.

Keywords: dielectric permittivity, specific conductivity, frequency, temperature, cryogenic rock, electromagnetic field.

\section{STATIC-DYNAMIC LOOSENING OF FROZEN ROCKS}

\section{(C) O. Terentiev, A. Klechov, M. Sergienko}

Loosening of frozen rocks and soils is one of the most complex, labor-intensive and economically costly technological processes in mining, energy and military complexes, construction of roads and industrial facilities, laying of canals, melioration and other industries. Of all rippers having mechanical means of destroying frozen rocks and soils, hydropneumatic percussion instruments are preferred. They destroy frozen rocks and soils at high dynamic loads.

Hydropneumatic shock mechanisms are characterized by high specific energy, autonomy of supply, compactness, simplicity of construction and control in work. Rippers with combined methods for the destruction of frozen rocks and soils are increasingly used.

This article presents the results of practical research on the loosening of frozen rocks and soils. The dependences of the change in the velocity of the antiphase ripper on the hydropneumatic hammer, the energy and frequency of the hammer blows are established.

Selected and substantiated operating parameters of the active ripper with anti-phase working active device. Industrial tests have confirmed that the optimal mode of active loosening of frozen rock with a frequency of shocks $\mathrm{C}=100 \ldots 110$ is the mode with an average speed of movement of the base machine $0.88 \mathrm{~m} / \mathrm{s}$ and activation of the tooth with energy of $7.5 \mathrm{~kJ}$ with a frequency of $2.0 \mathrm{~Hz}$. The optimality of this mode is confirmed by the minimum specific energy consumption of $1282 \mathrm{~kJ} / \mathrm{m}^{3}$, and with productivity of $0.175 \mathrm{~m}^{3} / \mathrm{s}$. Field trials of the active ripper were conducted in winter at a special polygon of Gorenichi village, Kyiv region. The freezing of the soil reached $1.1 \mathrm{~m}$. The effect of loosening depth on the loosening rate of the active loosening was studied with the traction power of the base machine at 0.16 and $0.24 \mathrm{MN}$. Active loosening was carried out at the coupling coefficient of the main machine with a surface of 0.4 and 0.6 , respectively. Changing the speed with increasing depth of the loosening is nonlinear. With increasing depth from 0.4 to $0.5 \mathrm{~m}$, the loosening speed decreases by $1.83,1.72$, and 174 times with the impact energy of 6.0, 7.0, and $8.0 \mathrm{~kJ}$, respectively. As the loosening depth increases from 0.5 to $0.6 \mathrm{~m}$, the intensity of the speed reduction decreases. In this case, the speed is reduced respectively by $1.52,1.45$ and 1.74 times. Increasing the loosening depth from 0.6 to $0.7 \mathrm{~m}$ leads to a decrease in the loosening rate by $1.29,1.23$ and 1.56 times, respectively.ly.

Keywords: frozen soil, tillage methods, rippers, productivity, tillage energy 
GEOCONSTRUCTION

\title{
RATIONALE OF THE EFFICIENCY OF APPLICATION MODERN MATERIALS IN FENCING STRUCTURES
}

\author{
(C) A. Han, S. Stovpnik, L. Shaidetska
}

Purpose. To investigate the nature of stress formation in the soil massif and its effect on the construction of the pit enclosure, depending on the types of construction materials and their strength characteristics. Methodology. Application of Midas GTS NX software for forming a stress-strain state of a soil array around a load-bearing enclosure based on finite element theory. Findings. According to the results of modeling, the regularities of changes in the deformation of the surrounding soil massif from the immersion depth of the load-bearing enclosure structure, the dependence of bending moments, transverse and longitudinal forces on a certain mark of the enclosing structure, and the composite concrete enclosure construction. Originality. On the basis of mathematical modeling, the bending moments of longitudinal and transverse forces are determined from a certain depth mark of concrete, reinforced concrete and composite concrete enclosing structures, and it is established that the greatest values of bending moments and longitudinal forces are at a depth of $6.5 \mathrm{~m}$ transverse forces are at a depth of $6 \mathrm{~m}$. The highest bending moment is $56 \mathrm{kN}^{*} \mathrm{~m}$ - for reinforced concrete structure, the slightly smaller bending moment in the composite concrete structure is $33 \mathrm{kN}^{*} \mathrm{~m}$ and the smallest bending moment in the concrete structure is $2.55 \mathrm{kN} * \mathrm{~m}$. A similar pattern is observed for longitudinal and transverse forces having values of $87 \mathrm{kN}$ and $-38 \mathrm{kN}$ for reinforced concrete structures, $83 \mathrm{kN}$ and $-28 \mathrm{kN}$ for composite concrete structures, $41 \mathrm{kN}$ and $2.7 \mathrm{kN}$ for concrete structures. Practical implications. On the basis of the obtained results, the expediency of the use of reinforced concrete and composite concrete enclosing structures, deformations of which are within the permissible values and are respectively: from 13,85 mm. up to $34.7 \mathrm{~mm}$ for composite concrete construction; from $14.13 \mathrm{~mm}$. up to $35.93 \mathrm{~mm}$ for reinforced concrete structure, which is confirmed by the test of cracks formation. Therefore, the use of non-metallic composite fittings in load-bearing enclosure structures is promising in modern construction.

Keywords: enclosure, stress-strain state, stress, concrete, reinforced concrete, composite concrete.

MINING ENGINEERING

\section{DEVELOPMENT OF STRUCTURES OF THE FLEXIBLE CONNECTION ASSEMBLY OF THE STEEL FRAME SUPPORT FOR RELIABILITY BY GAS FACTOR}

(C) H. Haiko, M. Bovkunovich

Purpose. Justification of design requirements and the development of the compliance node of the steel frame support for conditions dangerous for the gas factor.

Methodology. It included analysis and generalization of the operation of ductility nodes according to literature data, analysis of bench tests of ductile joints with identification of the mechanism and reasons for the formation of high-temperature heat pulses during dynamic slipping of support elements in typical assemblies, design of ductility duct for hazardous conditions by gas factor.

Findings. A historical excursus is given and the technical development of the ductility nodes of the steel frame support is shown, their effectiveness and safety are analyzed, design 
flaws and improvement directions are identified. The problem of explosive phenomena under dynamic loads on the frame support is considered. The mechanism of the emergence of hightemperature thermal pulses under dynamic loads of the frame, which can lead to the explosion of methane-air mixture in the mine atmosphere. To prevent hazardous events, a design of the compliance unit has been developed, based on the new layout of parts of a typical unit and close to it in cost. The technical effects of new structural elements that exclude explosive phenomena are achieved. For complex mining and geological operating conditions, a reinforced assembly design is proposed, which significantly (1.5-1.7 times) increases the force of sliding of the frame bearing elements in a flexible connection due to the concentration of compression forces of the profiles on their flanges and bottom.

Originality. It consists in the development of ideas about the causes of possible explosive phenomena under dynamic loads of the frame support.

Practical implications. It consists in the development of a safe, reliable and economical site of compliance of the steel frame support of the mine workings of coal mines hazardous for the gas factor.

Keywords: compliance node, special SVP profiles, steel frame support, heat pulse, mining safety.

\section{ECOLOGY AND LABOR PROTECTION}

\section{PREREQUISITES FOR THE DEVELOPMENT OF A NEW INFORMATION AND ANALYTICAL SYSTEM FOR THE EVALUATION OF THE COMPLEX OF HARMFUL AND DANGEROUS FACTORS DURING WELDING AND RELATED TECHNOLIGIES}

\section{(C) O. Levchenko, Y. Polukarov}

Purpose. Substantiation of necessity of creation of system of complex sanitary-hygienic assessment of harmful and dangerous factors at application of welding processes on the basis of integral safety index. Methodology. The analysis of a complex of harmful and dangerous factors affecting employees during the application of various welding methods and related technologies, as well as information and analytical systems, created to choose appropriate measures and remedies. On the basis of the analysis of harmful and dangerous factors of welding production and occupational diseases of workers in this field, the main measures aimed at improving the working conditions of welders were determined. Findings. A generalized "safety indicator" for different welding methods is proposed, which will take into account the complex of harmful and dangerous factors specific to a particular welding method for hygienically sound choice of welding method, welding materials and welding protection. Originality. The term "safety indicator" for different welding methods is proposed, which will be a mathematical model for estimation of harmful and dangerous factors specific to a particular welding method for the purpose of scientifically sound choice of welders protection based on the current hygienic classification. Practical implications. The necessity of development of a new information-analytical system on labor protection in welding production is substantiated and the main aspects and prospects of its application are outlined.

Keywords: electric welding; harmful and dangerous factors; protection measures; occupational disease; welding aerosol; information-analytical system. 